\title{
Echocardiographic findings in patent ductus arteriosus-associated infective endarteritis
}

\author{
Huitzilihuitl Saucedo-Orozco (iD, Jesús Vargas-Barrón* (iD, Clara A. Vázquez-Antona** (1), Francisco Castillo-Castellón*** (i) \\ Department of Cardioneumology, Centro Médico Nacional La Raza, Instituto Mexicano del Seguro Social; Mexico City-México \\ Departments of *Pharmacology, and **Pediatric Echocardiography, ***Tomography, Instituto Nacional de \\ Cardiología Ignacio Chávez; Mexico City-México
}

\section{ABSTRACT}

Objective: Infectious endarteritis associated with patent ductus arteriosus (PDA-IE) is an uncommon complication in the era of antibiotics. However, it implies a clinical challenge in patients with a fever of undetermined origin. Two-dimensional transthoracic echocardiography (TTE) plays a fundamental role in diagnosis and follow-up.

Methods: A retrospective analysis of the data of all patients admitted to our center with PDA-IE within 15 years was conducted, and a review of the literature regarding diagnosis, TTE findings, and treatment was performed.

Results: A total of 17 patients were identified with a mean age of 17.8 years. TTE done in all patients confirmed the diagnosis of PDA and pulmonary artery vegetation. In five patients, one vegetation was present; in three patients, two vegetations were found; and in the nine remaining patients, three or more vegetations were observed. In two-thirds of the patients, the size of the vegetation was three to $28 \mathrm{~mm}$, and the principal morphology was filiform. In all patients, at least one vegetation developed on the lateral wall of the ductus arteriosus. Pulmonary valve was affected in $41 \%$ of the patients and caused low to moderate valvular regurgitation. Pulmonary embolism was present in seven patients and pulmonary aneurysm in one patient.

Conclusion: The incidence of PDA-IE has decreased in the recent years with early antibiotic therapy. However, today, this complication carries a significant risk of valve damage and other cardiac structures' involvement.

Keywords: patent ductus arteriosus, endarteritis, echocardiography, congenital heart disease

Cite this article as: Saucedo-Orozco H, Vargas-Barrón J, Vázquez-Antona CA, Castillo-Castellón F. Echocardiographic findings in patent ductus arteriosusassociated infective endarteritis. Anatol J Cardiol 2021; 25: 774-80.

\section{Introduction}

The first patent ductus arteriosus (PDA) cases with infective endarteritis (IE) were described by Chevers in 1945 (1). This malformation is the consequence of a lack of closure of the ductus arteriosus (DA) after birth and is characterized by a tubular structure that connects the proximal part of the left pulmonary artery to the descending aorta. The incidence of term newborn infants having PDA is $1 / 2,000$. IE of the DA is a complication of PDA; furthermore, there is a risk of other complications such as septic pulmonary embolisms (PEm) and mycotic aneu- rysms in pulmonary arteries (PAn). The advent of echocardiography allowed for timely diagnosis through a noninvasive register. In 1985, Vargas-Barron et al. (2) reported the echocardiographic diagnosis of patent ductus arteriosus-associated infective endarteritis (PDA-IE) for the first time. Although antibiotics early, prophylaxis, and less delay in the diagnosis have caused a decrease in PDA-IE, the diagnosis and treatment are still challenging. This study aimed to show the echocardiographic characteristics, clinical association, diagnostic methods, clinical evolution, and complications in patients with PDA-IE and the literature review. 


\section{HIGHLIGHTS}

- Infectious endarteritis associated with patent ductus arteriosus is an uncommon complication in the era of antibiotics.

- In the majority of patients, the vegetation developed on the lateral wall of the ductus arteriosus.

- The pulmonary valve was affected in $41 \%$ of the patients and caused low to moderate valvular regurgitation.

\section{Methods}

The clinical records of 17 patients of various ages and sex diagnosed with PDA-IE with or without associated valvular malformations between January 2005 and December 2020 were retrospectively analyzed. Patients with other associated congenital heart diseases were excluded.

The images recorded from the two-dimensional (2D) transthoracic echocardiogram (TTE) or three-dimensional (3D) transesophageal echocardiogram (TEE) were reviewed upon the admission of the patient; the echocardiograms were performed with a Phillips IE-33, with PureWave cardiac transducer sector
S5-1 (1-5 MHz) and transesophageal probe in 4D X7-2t (2-7 $\mathrm{MHz}$ ) or pediatric transesophageal probe TEE S7-3t (3-7 MHz). A bibliographic search was carried out on diagnosis, echocardiographic findings, and treatment in patients with PDA-IE.

\section{Results}

The patients included 12 women and five men aged between 9 and 38 (mean 17.8) years. All admitted patients presented with fever, two presented with dyspnea, and one patient presented with heart failure. On physical examination, a continuous systolic murmur in the second left intercostal space was found in all patients (none with silent PDA). Four patients had cardiovascular defects, three patients had subaortic stenosis, and one patient had aortic coarctation. TTE was performed in all patients; in six, it was complemented with a TEE. In nine patients, cardiac computed tomography (CT) was done, and two cardiac magnetic resonance (MRI) images were used. The blood culture outcomes and the presence of complications are described in Table 1.

TTE done in 17 patients confirmed the diagnosis of PDA and PA vegetation (Videos 1-4); the median PDA diameter in all patients was $1.7 \mathrm{~mm}(0.9-4.0 \mathrm{~mm})$. In five patients, one vegetation was present; in three patients, two vegetations were found; and in the remaining nine patients, three or more vegetations were observed (Fig. 1, Table 1). In two-thirds of the patients, the

Table 1. Clinical characteristics of patients with PDA-IE at National Institute of Cardiology from 2005 to 2020

\begin{tabular}{|c|c|c|c|c|c|c|c|c|c|c|c|}
\hline \# & Sex & $\begin{array}{l}\text { Age } \\
\text { (years) }\end{array}$ & PA Veg & $\begin{array}{l}\text { Associated } \\
\text { Defects }\end{array}$ & $\begin{array}{l}\text { Diagnostic } \\
\text { Method }\end{array}$ & $\begin{array}{l}\text { Valvular } \\
\text { endocarditis }\end{array}$ & PAn & PEm & Blood culture & Treatment & Evolution \\
\hline 1 & $M$ & 9 & 1 & & TTE & - & - & - & Diphtheroids $s p$. & Ligature & $\mathrm{U} / \mathrm{E}$ \\
\hline 2 & $F$ & 10 & 1 & - & TTE & - & - & - & - & Ligature & $\mathrm{U} / \mathrm{E}$ \\
\hline 3 & $F$ & 16 & 1 & - & TTE & - & - & Yes & - & Ligature & $\mathrm{U} / \mathrm{E}$ \\
\hline 4 & $M$ & 11 & Several & AoCo & TTE & - & Yes & No & S. aureus & $\mathrm{OHS}$ & $\mathrm{U} / \mathrm{E}$ \\
\hline 5 & $\mathrm{~F}$ & 9 & 2 & SubAos & TTE/TEE & AoV & No & No & - & $\mathrm{OHS}$ & $\mathrm{U} / \mathrm{E}$ \\
\hline 6 & $F$ & 14 & 2 & - & TTE/TEE/CT & PV & No & Yes & St. viridans & $\mathrm{OHS}$ & $\mathrm{U} / \mathrm{E}$ \\
\hline 7 & $F$ & 15 & 2 & Sub AoS & ETT & AoV & No & No & - & $\mathrm{OHS}$ & $\mathrm{U} / \mathrm{E}$ \\
\hline 8 & $F$ & 16 & Several & - & ETT & PV & No & No & - & $\mathrm{OHS}$ & $\mathrm{U} / \mathrm{E}$ \\
\hline 9 & M & 21 & 2 & - & TTE/CT/MRI & PV & No & No & St. mitis & $\mathrm{OHS}$ & $\mathrm{U} / \mathrm{E}$ \\
\hline 10 & $F$ & 19 & Several & - & TTE/CT & PV & No & Yes & St. salivarius & $\mathrm{OHS}$ & $\mathrm{U} / \mathrm{E}$ \\
\hline 11 & $F$ & 38 & Several & Sub AoS & $\begin{array}{l}\text { TTE/TEE/CT/ } \\
\text { MRI }\end{array}$ & AoV, PV & No & No & St. viridans & $\mathrm{OHS}$ & Decease \\
\hline 12 & $M$ & 26 & 1 & - & TTE/TEE/MRI & - & No & No & St. mitis & $\mathrm{OHS}$ & $\mathrm{U} / \mathrm{E}$ \\
\hline 13 & $F$ & 23 & 2 & - & TTE/CT & PV & No & Yes & St. viridans & $\mathrm{OHS}$ & $\mathrm{U} / \mathrm{E}$ \\
\hline 14 & $M$ & 14 & 1 & - & $\begin{array}{l}\text { TTE/TEE/CT/ } \\
\text { MRI }\end{array}$ & - & No & No & St. viridans & $\mathrm{OHS}$ & $\mathrm{U} / \mathrm{E}$ \\
\hline 15 & $M$ & 33 & Several & - & TTE/CT & AoV & No & Yes & - & $\mathrm{OHS}$ & $\mathrm{U} / \mathrm{E}$ \\
\hline 16 & $M$ & 16 & 1 & - & TTE/CT & - & No & Yes & St. mutans & Amplatzer & $\mathrm{U} / \mathrm{E}$ \\
\hline 17 & M & 14 & Several & - & TTE/TEE/CT & PV & No & Yes & St. viridans & $\mathrm{OHS}$ & $\mathrm{U} / \mathrm{E}$ \\
\hline
\end{tabular}




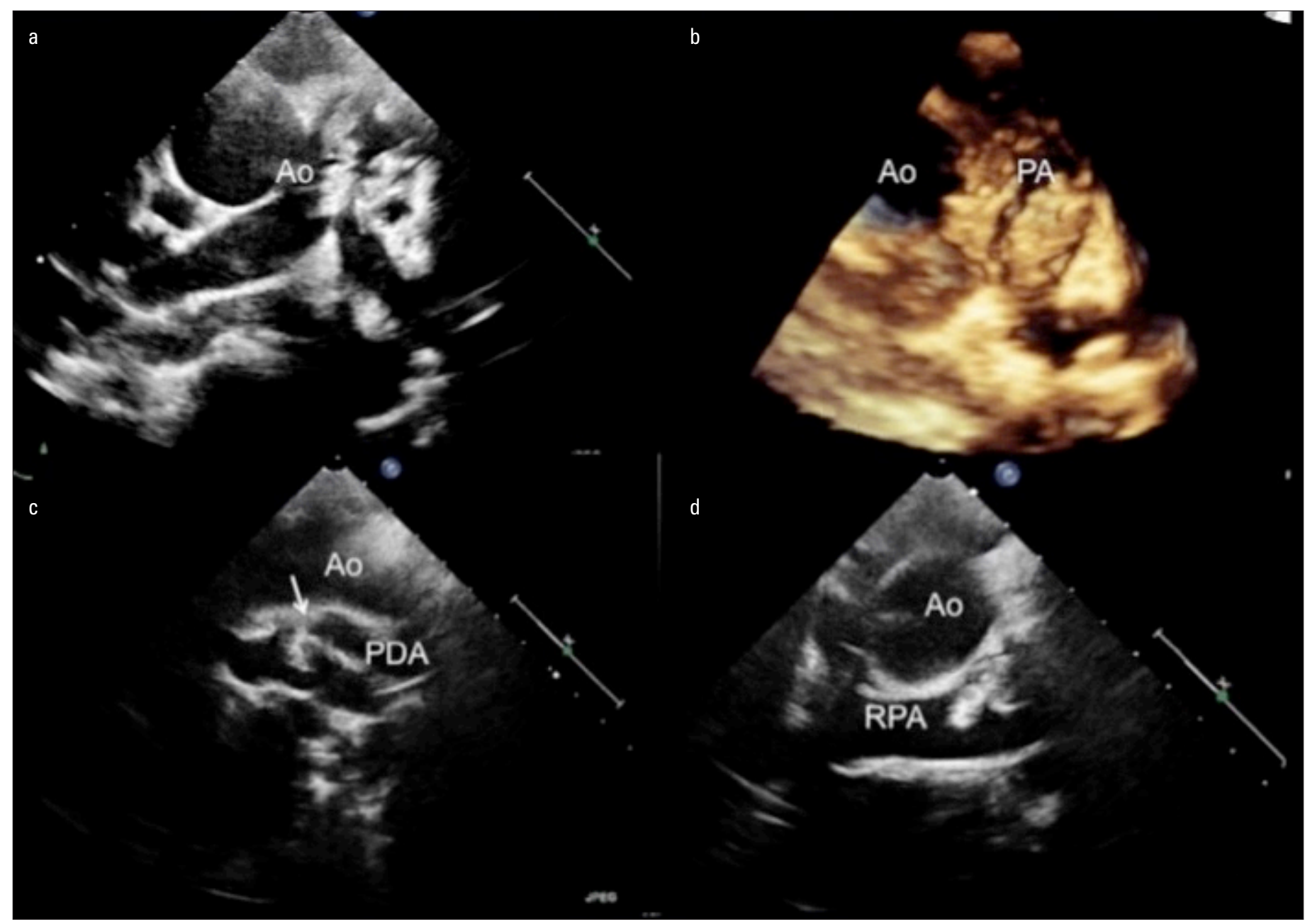

Figure 1. Transthoracic echocardiography images of a patient with infectious endarteritis associated with patent ductus arteriosus (PDA-IE), demonstrating multiple vegetations. A parasternal short-axis view shows two large vegetations in the valve and pulmonary trunk (a, b). The suprasternal axis view shows a large PDA (arrow) with vegetation (c, d)

vegetation size was 3-28 $\mathrm{mm}$, and the prime morphology was filiform. In the remaining patients, the principal and minor diameters were similar. In all patients, at least one vegetation developed on the lateral wall of the DA (Fig. 1). In seven (41\%) of the 17 patients, fragmentation of the vegetation led to septic PEm; in three patients, the embolism was caused by the whole vegetation. The size of the ductus did not determine the increase in pulmonary pressure nor was it related to the development of PEm. In one patient, the echocardiogram showed the development of PAn in the anterior wall, which initially developed on the site of the infectious vegetation implant. In nine patients, cardiac CT was performed; and in four cardiac patients, MRI was performed. The image studies helped establish the DA's size, infectious vegetations in the PA, and the cardiac valves (Table 1). Furthermore, they helped identify secondary pulmonary infarcts because of septic embolism and recognize PAn in segmentary pulmonary branches (Fig. 2 and Fig. 3).

Thirteen patients were surgically treated with extracorporeal circulation. Ductus ligatures were performed in three patients, and transpulmonary corrections were done in 10 patients. In the three remaining patients, a ligature of the DA without extracorporeal circulation was performed. Regarding valvular participation in the infectious process, owing to its proximity, the pulmonary valve (PV) was the most affected. In seven $(41 \%)$ of the 17 patients, vegetations that caused mild to moderate valvular regurgitation were registered. The serial echocardiographic studies showed that antibiotic treatment reduced the size of the vegetations that were localized in PV and PA. The excellent clinical evolution allowed for the revision of only the ventral wall during the surgical correction of the DA in five patients. In the two remaining patients, the valvular damage motivated its replacement with a biological prosthesis. The aortic valve participated in the infectious process in four patients $(23 \%)$. In three of them, the presence of a subvalvular aortic fibrous membrane promoted valvular damage and the development of vegetation. In the fourth patient, the aortic valve was bicuspid. In three patients, surgery included the replacement of the aortic valve and the resection of the subvalvular aortic membrane. In one of the five patients who required valvular replacement, it was necessary to change both the aortic and the PVs. In one patient, the treatment was percutaneous interventionism (Amplatzer device) 

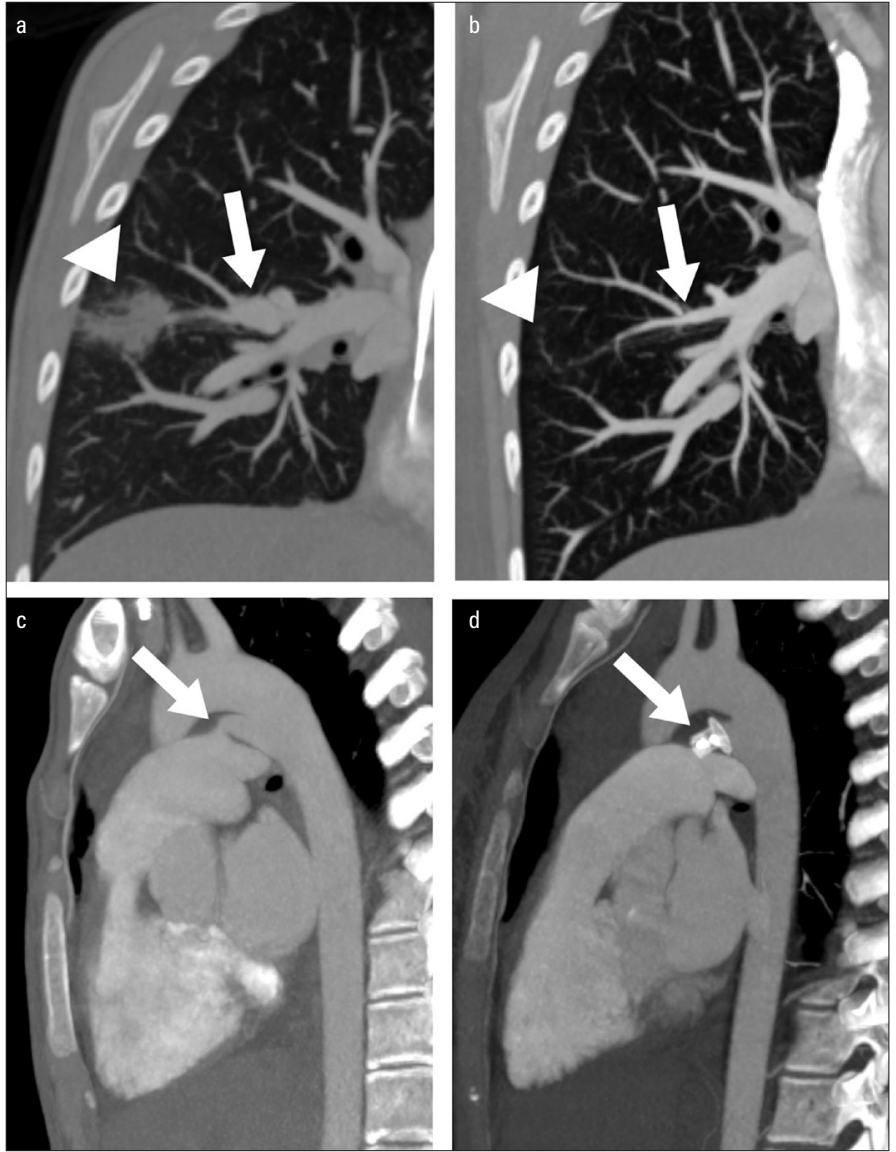

Figure 2. Chest computed tomography (CT) in coronal view (a) showing an aneurysm of the right lower pulmonary artery (PA) (arrowhead), followed by a periphery infarct (arrow). CT after two years (b) showing regression of the PA aneurysm. Patent ductus arteriosus in a candy cane aorta view before (c) and after (d)
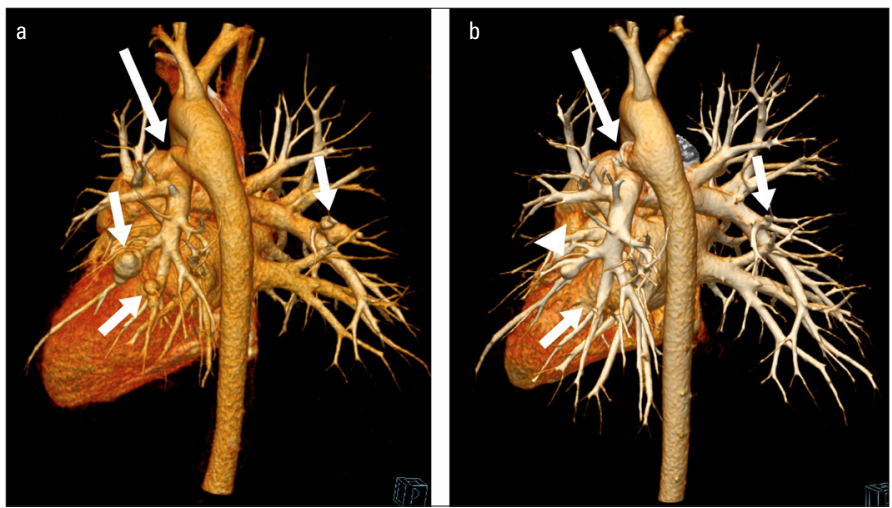

Figure 3. Computed tomography (CT) volume rendering in posterior view (a) showing bilateral pulmonary aneurysms (small arrows), and CT after two years (b) demonstrating a complete (small arrows) or partial (arrowhead) regression. Patent ductus arteriosus before (a) and after (b) percutaneous closure

three months after the IE resolution (Fig. 2). Resolution was satisfactory in 16 of the 17 patients, and only one patient who had a PDA-IE and subaortic stenosis with infective vegetations in the pulmonary and aortic valves died after surgery.

\section{Discussion}

This study reports the most extensive series of patients with PDA-IE studied by echocardiography (and some with cardiac $\mathrm{MRI}$ or cardiac CT) in the literature and presents similarities with some previous publications (Table 2) (2-28). In recent years, the incidence of PDA-IE has decreased owing to the use of antimicrobial prophylaxis in high-risk patients (prosthetic valve, previous IE, and congenital heart disease) (29-31).

We believe that the echocardiographic search of IE in PA should not only include cases with PDA and fever but should also be used in patients with bacteremia of uncertain origin and with any murmur and fever. The search should be performed mainly in children and young adults, although there are reports of PDA in patients between 75 and 95 years old who can have pulmonary IE and valvular endocarditis (32). The use of TTE has constituted an essential factor in the detection of PDA; when the TTE is negative and there is a high rate of probability of $\mathrm{IE}$, or when the registers are of suboptimal quality, the echocardiographic study should be a TEE.

Associated cardiovascular defects were rarely reported in patients with endarteritis because of PDA. Only three patients were found in 24 publications (pulmonary stenosis, coarctation of the aorta, and rheumatic valve disease) (6-22). It is worth noting that subvalvular aortic stenosis was present in three of the 17 patients in our study group. The subaortic stenosis further facilitated the infectious implant in the aortic valve with the development of vegetations and the need to perform a valvular replacement. There was one death of an adult woman with a fibrous subaortic membrane and infectious endocarditis in the aortic and pulmonary valves. It should be recommended that in patients with PDA, an echocardiographic study, including the aortic subvalvular region, be done.

In patients with PDA-IE, serial echocardiograms should explore the PV because its participation in the infectious process is frequent [in $7(41 \%)$ of 17 patients] (8-12). In these patients, adequate antibiotic treatments allow an excellent evolution, including reduction or even relapse of vegetations. This resulted in the corrective surgery limitation only to the DA's closure in five of seven patients; in the two remaining patients, a valvular replacement was necessary. The development of septic embolism from the vegetations in the PA is frequent. In the 27 publications with image studies, it was found in $36.5 \%$ of the 41 patients (Table 2). In our study series, it was detected in $41 \%$ patients. In most patients, the evolution of PEm is satisfactory with antibiotic treatment.

DA with remedied IE can be surgically or percutaneously treated. In our study group, 16 of the 17 patients were surgically treated; transpulmonary correction with extracorporeal circulation was performed in 13 patients; and a ligature of the DA was performed in the remaining three patients. The corrective surgery of DA with IE represented a spectacular change in the prognosis of these patients. In patients with an extensive infectious process that involves the PA wall or in those who do not respond to antibiotics, surgery with extracorporeal circulation is 


\begin{tabular}{|c|c|c|c|c|c|c|c|c|c|c|c|}
\hline Author & Year & Sex & Age & $\begin{array}{l}\text { Imaging } \\
\text { method }\end{array}$ & PEm & PAn & Blood culture & $\begin{array}{l}\text { Valvular } \\
\text { SBE }\end{array}$ & $\begin{array}{l}\text { Associated } \\
\text { defects }\end{array}$ & Treatment & Follow-up \\
\hline $\begin{array}{l}\text { Vargas-Barron } \\
\text { et al. (2) }\end{array}$ & 1985 & $\mathrm{M}$ & 9 & TTE & Yes & No & Diphtheroids sp. & No & No & Ligature & $\mathrm{U} / \mathrm{E}$ \\
\hline Chia et al. (3) & 1987 & $\mathrm{~F}$ & 16 & TTE & No & No & $\begin{array}{l}\text { Candida } \\
\text { parapsilosis }\end{array}$ & No & No & $\mathrm{OHS}$ & $\mathrm{U} / \mathrm{E}$ \\
\hline Andrade-Freire & 1987 & $\mathrm{~F}$ & 10 & TTE & No & No & - & - & - & Ligature & $\mathrm{U} / \mathrm{E}$ \\
\hline et al. (4) & & $\mathrm{F}$ & 16 & TEE & Yes & No & - & - & - & & \\
\hline $\begin{array}{l}\text { Stejskal and } \\
\text { Stark (5) }\end{array}$ & 1992 & $\mathrm{~F}$ & 7 & TTE & Yes & No & St. viridans & No & No & OHS & $\mathrm{U} / \mathrm{E}$ \\
\hline $\begin{array}{l}\text { Vargas-Barron } \\
\text { et al. (6) }\end{array}$ & 1992 & $\mathrm{~F}$ & 11 & TTE & No & Yes & S. aureus & No & AoCo & $\begin{array}{l}\text { OHS / PAn } \\
\text { resection }\end{array}$ & $\mathrm{U} / \mathrm{E}$ \\
\hline Balzer et al. (7) & 1993 & $\mathrm{M}$ & 19 & TTE & No & No & S. aureus & No & No & Ligature & $\mathrm{U} / \mathrm{E}$ \\
\hline Rivera et al. (8) & 1997 & $\mathrm{~F}$ & 7 & TTE & Yes & No & St. milleri & PV & No & Ligature & $\mathrm{U} / \mathrm{E}$ \\
\hline Yanýk et al. (9) & 2000 & $\mathrm{M}$ & 14 & TTE & No & No & St. viridans & No & No & Ligature & $\mathrm{U} / \mathrm{E}$ \\
\hline $\begin{array}{l}\text { Parthenakis } \\
\text { et al. (10) }\end{array}$ & 2000 & $\mathrm{~F}$ & 18 & TTE & No & No & St. sanguis & No & No & Ligature & $\mathrm{U} / \mathrm{E}$ \\
\hline Kouris et al. (11) & 2003 & $\mathrm{~F}$ & 43 & TTE/TEE & Yes & No & St. sanguis & No & No & Ligature & $\mathrm{U} / \mathrm{E}$ \\
\hline Sadiq et al. (12) & 2004 & $\begin{array}{l}14 \\
\text { cases }\end{array}$ & $\begin{array}{l}\text { less } \\
\text { than } 16\end{array}$ & TTE & $1 / 14$ & - & $\begin{array}{l}6 / 14 \\
\text { St. viridans (2) } \\
\text { S. aureus (4) }\end{array}$ & PV (2) & No & $\begin{array}{l}\text { Cath lab } 8 \\
\text { Ligature } 5 \\
\text { Antibiotics } 1\end{array}$ & $\mathrm{U} / \mathrm{E}$ \\
\hline Bilge et al. (13) & 2004 & $\mathrm{~F}$ & 11 & TTE & Yes & No & St. viridans & No & No & Ligature & $U / E$ \\
\hline Kadakia et al. (14) & 2004 & $\mathrm{M}$ & 25 & TTE & No & No & St. mutans & No & No & Antibiotics & - \\
\hline $\begin{array}{l}\text { Cerruto and } \\
\text { Mancuso (15) }\end{array}$ & 2005 & $\mathrm{~F}$ & 50 & TTE/TEE & Yes & No & $\begin{array}{l}\text { Corynebacterium } \\
\text { Pseudodiphtheria }\end{array}$ & AoV & - & Antibiotics & AMI Death \\
\hline Lankipalli et al. (16) & 2005 & $\mathrm{M}$ & 64 & $\begin{array}{l}\text { TTE/TEE/ } \\
\text { MRI }\end{array}$ & No & No & Gamella Sp. & No & No & OHS & $\mathrm{U} / \mathrm{E}$ \\
\hline $\begin{array}{l}\text { Cruz-González } \\
\text { et al. (17) }\end{array}$ & 2006 & $\mathrm{~F}$ & 56 & TTE & Yes & No & St. viridans & No & No & Antibiotics & - \\
\hline $\begin{array}{l}\text { Onji and Matsuura } \\
\text { (18) }\end{array}$ & 2007 & $\mathrm{M}$ & 49 & TTE/CT & Yes & No & St. mitis & No & No & Ligature & $\mathrm{U} / \mathrm{E}$ \\
\hline Celebi et al. (19) & 2007 & $\mathrm{M}$ & $\begin{array}{l}2 \\
\text { months }\end{array}$ & TTE & No & No & St. B Hemolytic & No & No & Ligation & $\mathrm{U} / \mathrm{E}$ \\
\hline Kiani et al. (20) & 2008 & $\mathrm{M}$ & 5 & TTE & No & Yes & - & No & No & $\begin{array}{l}\text { Ligation / } \\
\text { Aneurysm } \\
\text { resection }\end{array}$ & $U / E$ \\
\hline Bathoorn et al. (21) & 2009 & $\mathrm{~F}$ & 62 & CT & Yes & No & - & No & No & Amplatzer & $\mathrm{U} / \mathrm{E}$ \\
\hline Cagli et al. (22) & 2010 & $\mathrm{~F}$ & 27 & TTE & Yes & No & - & AoV/MV & $\mathrm{RHD}$ & $\begin{array}{l}\mathrm{OHS}+\mathrm{MV} \\
\text { and AoV } \\
\text { prosthesis }\end{array}$ & $\mathrm{U} / \mathrm{E}$ \\
\hline $\begin{array}{l}\text { Matsukuma } \\
\text { et al. (23) }\end{array}$ & 2011 & $\mathrm{M}$ & 35 & TTE & Yes & No & S. aureus & No & No & $\mathrm{OHS}$ & $\mathrm{U} / \mathrm{E}$ \\
\hline $\begin{array}{l}\text { Navaratnarajah } \\
\text { et al. (24) }\end{array}$ & 2011 & $\mathrm{M}$ & 34 & TTE/TEE & Yes & No & St. viridans & No & No & $\mathrm{OHS}$ & $U / E$ \\
\hline Sugimura et al. (25) & 2013 & $\mathrm{~F}$ & 63 & TEE/CT & No & No & $\begin{array}{l}\text { Pseudomonas } \\
\text { aerus }\end{array}$ & No & No & OHS & $\mathrm{U} / \mathrm{E}$ \\
\hline Miraclin et al. (26) & 2017 & $\mathrm{~F}$ & 54 & CT/MRI & No & No & $\begin{array}{l}\text { Abiotrophia } \\
\text { defective }\end{array}$ & No & No & Antibiotics & $\mathrm{U} / \mathrm{E}$ \\
\hline Callegari et al. (27) & 2019 & $\mathrm{M}$ & 7 weeks & TTE & No & No & S. aureus & No & No & Antibiotics & $U / E$ \\
\hline Lee et al. (28) & 2020 & $\mathrm{~F}$ & 42 & CT & Yes & No & - & No & No & Antibiotics & Death \\
\hline
\end{tabular}


a better option than a simple ligature. When the vegetations are small and reduced or disappear with antibiotics, a simple ligature is the best option $(5,32)$.

Nowadays, there is no disagreement with percutaneous closure as the elective treatment in infants with PDA (33). Percutaneous closure is suggested in adults also to prevent IE and heart failure and should be performed before decreased left ventricular ejection fraction. The presence of vegetations in the PA is not a contraindication for percutaneous closure of the PDA. In these patients, antibiotics are suggested under echocardiographic follow-up, and the device could be set once the infection has been controlled.

\section{Study limitations}

As it was a retrospective study, the prevalence of PDA-IE is unknown in a reference center, and the sample size was small.

\section{Conclusion}

The use of two-dimensional transthoracic echocardiography is trustworthy and reliable to confirm the diagnosis of infective endocarditis; the number and size of vegetations are variable. The main shape of the vegetations is filiform; in most patients, it is located on the lateral wall of the DA. The PV is frequently affected by continuity; fortunately, in most patients, it can be corrected with conservative medical treatment. Finally, serial echocardiographic studies help decide the type of corrective treatment, either percutaneous or surgical according to the vegetations' evolution.

Ethics approval: Ethics committee updated and approved by the Ethics and Research Committee of the National Institute of Cardiology “Ignacio Chávez". Date: September 20, 2021, Number: INCAR-DG-DC$\mathrm{Cl}$-199-2021. This study is retrospective, and we only review clinical and echocardiography data.

Conflict of interest: None declared.

Peer-review: Externally peer-reviewed.

Author contributions: Concept - H.S.O.; Design - H.S.O.; Supervision - H.S.O.; Fundings - H.S.O., J.V.B., C.A.V.A., F.C.C.; Materials - H.S.O.; Data collection \&/or processing - J.V.B., C.A.V.A.; Analysis \&/or interpretation - J.V.B., C.A.V.A.; Literature search - F.C.C.; Writing - J.V.B., C.A.V.A.; Critical review - J.V.B., C.A.V.A.

Video 1. Two-dimensional transthoracic echocardiography in the parasternal short-axis view

Video 2. Three-dimensional transthoracic echocardiography showing two large vegetations on the valve and pulmonary trunk

Video 3. Two-dimensional transthoracic echocardiography in suprasternal view

Video 4. Two-dimensional transthoracic echocardiography in short suprasternal view

\section{References}

1. Chevers N. Observations on the permanence of the ductus arteriosus, and constriction of the thoracic aorta. London M Gaz 1945; 36: 187.

2. Vargas-Barron J, Attie F, Buendia-Hernandez A, Keirns C, EsquivelAvila J. Echocardiographic recognition of pulmonary artery endarteritis in patent ductus arteriosus. Am Heart J 1985; 109: 368-70. [Crossref]

3. Chia BL, Ee BK, Choo MH, Tan NC. Two-dimensional echocardiographic features of pulmonary artery vegetation. Am Heart J 1987; 113: 833-4. [Crossref]

4. Andrade-Freire A, Vargás-Barrón J, Attie F, Santana González A, Gual Julia J, Vicente Vera T. Echocardiographic recognition of endarteritis of the pulmonary artery in patent ductus arteriosus. Arch Inst Cardiol Mex 1987; 57: 291-3. [Article in Spanish]

5. Stejskal L, Stark J. Surgical treatment of persistent ductus arteriosus complicated by bacterial endocarditis. Eur $\mathrm{J}$ Cardiothorac Surg 1992; 6: 272-3. [Crossref]

6. Vargas-Barron J, Avila-Rosales L, Romero-Cardenas A, Rijlaarsdam M, Keirns C, Buendia A. Echocardiographic diagnosis of a mycotic aneurysm of the main pulmonary artery and patent ductus arteriosus. Am Heart J 1992; 123: 1707-9. [Crossref]

7. Balzer DT, Spray TL, McMullin D, Cottingham W, Canter CE. Endarteritis associated with a clinically silent patent ductus arteriosus. Am Heart J 1993; 125: 1192-3. [Crossref]

8. Rivera IR, Moisés VA, Brandão AC, Silva CC, Andrade JL, Carvalho AC. Patent ductus arteriosus and pulmonary artery endarteritis. Arq Bras Cardiol 1997; 69: 335-8. [Article in Portuguese] [Crossref]

9. Yanýk A, Yetkin E, Lleri M, Yetkin G, Penen K, Göskel S. Vegetation due to Streptococcus viridans in the pulmonary artery in a child with patent ductus arteriosus. Int J Cardiol 2000; 72: 189-91. [Crossref]

10. Parthenakis Fl, Kanakaraki MK, Vardas PE. Images in cardiology: silent patent ductus arteriosus endarteritis. Heart 2000; 84: 619. [Crossref]

11. Kouris NT, Sifaki MD, Kontogianni DD, Zaharos I, Kalkandi EM, Grassos HE, et al. Patent ductus arteriosus endarteritis in a 40-year old woman, diagnosed with transesophageal echocardiography. A case report and a brief review of the literature. Cardiovasc Ultrasound 2003; 1: 2. [Crossref]

12. Sadiq M, Latif $F$, Ur-Rehman A. Analysis of infective endarteritis in patent ductus arteriosus. Am J Cardiol 2004; 93: 513-5. [Crossref]

13. Bilge M, Uner A, Ozeren A, Aydin M, Demirel F, Ermiş B, Ozkökeli M. Pulmonary endarteritis and subsequent embolization to the lung as a complication of a patent ductus arteriosus--a case report. Angiology 2004; 55: 99-102. [Crossref]

14. Kadakia R, Giullian J, Dokainish H. Patent ductus arteriosus complicated by pulmonary artery endarteritis in an adult. Echocardiography 2004; 21: 665-7. [Crossref]

15. Cerruto G, Mancuso L. Systemic and pulmonary embolization in a patient with patent ductus arteriosus. Eur J Echocardiogr 2005; 6: 376-8. [Crossref]

16. Lankipalli RS, Lax K, Keane MG, Toca FM, Bavaria JE, Milas BL, et al. Images in cardiovascular medicine. Infected patent ductus arteriosus. Circulation 2005; 112: e364-5. [Crossref]

17. Cruz-González I, Martín-Herrero F, Sánchez JL. Infective endarteritis in patent ductus arteriosus and septic pulmonary embolism. Rev Esp Cardiol 2006; 59: 397-8. [Article in Spanish] [Crossref]

18. Onji K, Matsuura W. Pulmonary endarteritis and subsequent pulmonary embolism associated with clinically silent patent ductus arteriosus. Intern Med 2007; 46: 1663-7. [Crossref] 
19. Celebi A, Erdem A, Cokuğraş H, Ahunbay G. Infective endarteritis in a 2-month-old infant associated with silent patent ductus arteriosus. Anatol J Cardiol 2007; 7: 325-7.

20. Kiani A, Radmehr H, Shabanian R. Pulmonary artery aneurysm in a child secondary to infective endarteritis. Pediatr Cardiol 2008; 29: 471-2. [Crossref]

21. Bathoorn $E$, Heitbrink MA, Reichert CL, Boersma WG. A turbulent cause of bilateral pneumonia. Eur Respir J 2009; 33: 1513-6. [Crossref]

22. Cagli K, Basar FN, Cagli K, Yalcinkaya A, Ozeke 0, Turhan N, et al. Multisite infective endocarditis/endarteritis in a young peripartum patient with patent ductus arteriosus and rheumatic heart valve disease: a case report. Echocardiography 2010; 27: 466-9. [Crossref]

23. Matsukuma S, Eishi K, Hashizume K, Oshitomi T, Ariyoshi T, Taniguchi $S$, et al. A case of pulmonary infective endarteritis associated with patent ductus arteriosus: surgical closure under circulatory arrest. Gen Thorac Cardiovasc Surg 2011; 59: 563-5. [Crossref]

24. Navaratnarajah M, Mensah K, Balakrishnan M, Raja SG, Bahrami T. Large patent ductus arteriosus in an adult complicated by pulmonary endarteritis and embolic lung abscess. Heart Int 2011; 6: e16. [Crossref]

25. Sugimura $Y$, Katoh M, Toyama $M$. Patent ductus arteriosus with pulmonary endarteritis. Intern Med 2013; 52: 2157-8. [Crossref]

26. Miraclin AT, Perumalla SK, Daniel J, Sathyendra S. Abiotrophia defectiva endarteritis with infective spondylodiscitis in an adult patient with patent ductus arteriosus. BMJ Case Rep 2017; 2017: bcr2017219295. [Crossref]

27. Callegari A, Burkhardt B, Relly C, Knirsch W, Christmann M. Ductus arteriosus-associated infective endarteritis: Lessons from the past, future perspective. Congenit Heart Dis 2019; 14: 671-7. [Crossref]

28. Lee D, Yoo SM, Lee HY, White CS. Computed Tomography Diagnosis of Patent Ductus Arteriosus Endarteritis and Septic Pulmonary Embolism. Korean Circ J 2020; 50: 182-3. [Crossref]
29. Wilson W, Taubert KA, Gewitz M, Lockhart PB, Baddour LM, Levison M, et al.; American Heart Association Rheumatic Fever, Endocarditis, and Kawasaki Disease Committee; American Heart Association Council on Cardiovascular Disease in the Young; American Heart Association Council on Clinical Cardiology; American Heart Association Council on Cardiovascular Surgery and Anesthesia; Quality of Care and Outcomes Research Interdisciplinary Working Group. Prevention of infective endocarditis: guidelines from the American Heart Association: a guideline from the American Heart Association Rheumatic Fever, Endocarditis, and Kawasaki Disease Committee, Council on Cardiovascular Disease in the Young, and the Council on Clinical Cardiology, Council on Cardiovascular Surgery and Anesthesia, and the Quality of Care and Outcomes Research Interdisciplinary Working Group. Circulation 2007; 116: 1736-54. [Crossref]

30. Østergaard L, Valeur N, Ihlemann N, Bundgaard H, Gislason G, Torp-Pedersen $\mathrm{C}$, et al. Incidence of infective endocarditis among patients considered at high risk. Eur Heart J 2018; 39: 623-9. [Crossref]

31. Habib G, Lancellotti P, Antunes MJ, Bongiorni MG, Casalta JP, Del Zotti F, et al.; ESC Scientific Document Group. 2015 ESC Guidelines for the management of infective endocarditis: The Task Force for the Management of Infective Endocarditis of the European Society of Cardiology (ESC). Endorsed by: European Association for CardioThoracic Surgery (EACTS), the European Association of Nuclear Medicine (EANM). Eur Heart J 2015; 36: 3075-128. [Crossref]

32. Wiyono SA, Witsenburg M, de Jaegere PP, Roos-Hesselink JW. Patent ductus arteriosus in adults: Case report and review illustrating the spectrum of the disease. Neth Heart J 2008; 16: 255-9. [Crossref]

33. Vázquez-Antona CA, Rijlaarsdam M, Gaspar J, Gil Moreno M, Buendía Hernández A, Martínez Ríos MA, et al. The transcatheter closure of patent ductus arteriosus. The initial experience. Arch Inst Cardiol Mex 1993; 63: 493-9. [Article in Spanish] 